\title{
Biodiversity as a tool for waste phycoremediation and biomass production
}

\author{
Eric Fouilland
}

Published online: 24 February 2012

(C) Springer Science+Business Media B.V. 2012

Over the past 20 years, plants have been used to an increasing extent in various environments for mitigating pollutant concentrations in contaminated sites (soils or waters) and for producing biodiesel. However, because plant growth rates and biomass yields are low and because a considerable amount of water and large surface area are required, intensive cultivation of microalgae has been proposed as an alternative method for phycoremediation and producing bioenergy (Dismukes et al. 2008; Rawat et al. 2011). However, mass cultivation of microalgae in open systems (and, to a certain extent, in closed systems) is subject to strong competition (from local microalgal communities when single species microalgal bioprocesses are considered) and predation and are particularly sensitive to sudden changes in environmental conditions (light, temperature and nutrient availability). Such factors may contribute to the rapid collapse of the microalgae culture. The use of indigenous microalgae species for local intensive production, better adapted to local climatic conditions, may reduce potential competition to some extent without risk of the culture becoming noxious or invasive, as claimed recently by Wilkie et al. (2011). However, the stability

E. Fouilland $(\square)$

UMR 5119 ECOSYM, Université Montpellier 2, CNRS,

IRD, IFREMER, Université Montpellier 1,

Station Méditerranéenne de l'Environnement Littoral,

2 rue des Chantiers, 34200 Sète, France

e-mail: Eric.Fouilland@univ-montp2.fr of microalgal productivity in a single species culture is doubtful when cultures are supplied with heterogeneous wastewaters containing various organic and inorganic compounds, some of which are toxic, together with their own microbial communities feeding on the waste.

The application of ecological observations of natural ecosystems to large-scale microalgal cultivation might help to ensure successful, intensive, stable mass algal production by increasing the efficiency of multiple resource use and by reducing potential competition and predation.

\section{Exploiting microalgal diversity}

Recent studies have shown positive relationships between microalgae diversity and resource (phosphorus, nitrate) use efficiency in freshwater and brackish communities (Ptacnik et al. 2008; Cardinale 2011). Algal communities with greater species richness make better use of niche opportunities in an environment, allowing them to capture a higher proportion of available resources (Cardinale 2011). The great variety of nutrition modes displayed by microalgae species for acquiring carbon or nutrients helps to extend their niche opportunities in changing environments. Depending on the species, their physiology, cell size and biotic and abiotic environmental growth conditions, microalgae can use various forms of nitrogen (elemental nitrogen, ammonium, nitrate, organic 
nitrogen) or particulate organic substances for growth (Raven 1997; Stoecker 1999; Granéli et al. 1999). For example, some Chrysophytes, Prymnesiophytes, Dinophytes and Cryptophytes species have been reported as consuming dissolved organic matter (Granéli et al. 1999) or ingesting particles (Caron 2000). These species are usually observed in low light environments occasionally submitted to strong riverine inputs (coastal marine waters and estuaries). Furthermore, microalgae have developed the production of peptides that are able to bind heavy metals, but this binding efficiency is species dependent (Wide and Bennan 1993) and varies with cell size, shape and cell wall composition (Tam et al. 1997).

The culture of mixed microalgal species (polyculture), combining species with different metabolic abilities (e.g. the use of different forms of N, C and contaminants) may improve the overall remediation capacity of cultures when supplemented with multiple resources. This is supported by the results of a recent study ( $\mathrm{Li}$ et al. 2012) which showed that cadmium removal efficiency increased with microalgal (Chlorophytes) species richness. Assemblies of algal species (a mixture of mixotrophic species-Chinnasamy et al. 2010, a mixture of cyanobacterial species-Dubey et al. 2011, and a mixture of diatoms and Chlorophytes-Ventaka Mohan et al. 2011), supplied with domestic and industrial contaminated waters, were successfully cultivated and resulted, respectively, in high biomass productivity $\left(21 \mathrm{~g} \mathrm{~m}^{-2}\right.$ day $\left.^{-1}\right)$, up to $100 \%$ removal of contaminants and the production of lipids suitable for biodiesel.

Given the wide variety of metabolisms developed by microalgae observed in nature, growing in all habitats even in extreme environments, the use of a cultivation method based on mixed species with different specific metabolic capabilities requires extensive investigation to explore all possible combinations of species. It may be possible to use polycultures combining, for example, both photoautotrophs and mixotrophs, or ammonia and nitrate users, to improve not only the productivity of the cultures but also their resilience.

\section{Benefits of microalgae-bacteria associations}

In natural aquatic environments, ecosystems with high microalgal production are always associated with strong heterotrophic bacterial production (Fouilland and Mostajir 2010). This suggests a close interaction between the various microbial communities. However, little is known about the nature of such associations (independence, competition, mutualism, or symbiosis) and is still debated (Fouilland and Mostajir 2011). Bacteria may support the photoautrophic growth of microalgae by providing $\mathrm{CO}_{2}$, ammonia and vitamins for example, and may assimilate organic carbon losses through microalgal exudation for their own growth. In turn, microalgal photosynthesis provides the $\mathrm{O}_{2}$ required by organic matter-degrading heterotrophic bacteria. Potential competition between microalgae and bacteria for nutrients makes their relationships more complex (Grover 2000 and references therein). Few studies have been undertaken into the association of microalgal species and heterotrophic bacteria for removing nutrients from wastewaters and for detoxifying water of organic and inorganic pollutants (Muñoz and Guieysse 2006; Tang et al. 2011) and the biotechnological potential of such associations was recently reviewed (Subashchandrabose et al. 2011). Nevertheless, further investigation using natural and artificial microalgae-bacteria associations is still required (1) to understand the role of environmental growth conditions (e.g. light intensity and frequency, concentration and $\mathrm{C}: \mathrm{N}: \mathrm{P}$ ratio of nutrients), (2) to characterize the importance of diversity on these microbial interactions and (3) to evaluate the consequence on consortium productivity and remediation capacity. The results will help to optimize the parameters for the operation of reactors and open ponds for the degradation of various pollutants and biomass production.

\section{Exploring marine biodiversity}

Fewer than 5,000 marine species have so far been described and most of the current diversity is probably still undescribed, especially in the small size fraction (a few micrometers) (Simon et al. 2009). In this fraction, widespread microalgae may have several clades whose genetic divergence is greater than the divergence estimated between traditional genera (Simon et al. 2009). Such high genetic variability allows them to occupy several specific niches. The combination of high genetic and metabolic variability may explain, for example, the very high biomass 
turnover rates (up to 8 day $^{-1}$ ) achieved by such small microalgae with various sources of nitrogen (Fouilland et al. 2004). Although marine microalgae species appear to be good candidates for oil production (e.g. Tetraselmis suecica, Dunaliella tertiolecta, Nannochloropsis spp.) with higher biomass productivity and lipid content than freshwater species (Rodolfi et al. 2009), very little is known about their ability to grow in wastewater. Marine microalgae are resilient to salinity changes through the synthesis or degradation of compatible solutes (Wegmann 1986) allowing cultivation using freshwater. The high productivity and metabolic diversity usually observed in natural marine coastal waters submitted to considerable variation in salinity and nutrients (Costanza et al. 1993), suggest that marine microalgae may be a sustainable alternative for algal mass production using wastewater. This is supported by the few published studies on marine microalgae species using wastewater and $\mathrm{CO}_{2}$ from flue gases for high biomass production, nutrient removal and lipid production (Jiang et al. 2011 and references therein).

As hardly anything is known about the potential of marine microalgae for phycoremediation and intensive biomass production, this would be a valuable line of further research. The use of brackish waters for intensive algal cultivation would also act as an osmotic barrier for potential competitors and predators (Logares et al. 2009) and avoid the consumption of freshwater.

In conclusion, research should be undertaken into the production of biomass combined with wastewater remediation through intensive microalgal cultivation, focusing on polycultures with assemblies of species with specific metabolic capacities such as mixotrophy, specific metal binding abilities, different preferential $\mathrm{N}$ forms and euryhalinity. The complexity of the interactions between microalgae and heterotrophic bacteria should be investigated to benefit from bacteria omnipresent in algal cultures. The design and use of such microbial consortia dedicated to specific or general purposes is the direct application of the concept of ecological engineering at microbial scale. This might result in assembled microbial consortia providing a more resilient and efficient biomass production when supplied with heterogeneous wastewaters, leading to more efficient removal of inorganic, organic and metallic liquid pollutants.
Acknowledgments This paper is a contribution to the SYMBIOSE project (ANR-08-BIOE-11) funded by the French National Research Agency (ANR). The paper draws on fruitful discussions with my colleagues, Bruno Sialve, Christophe Vasseur, and Christophe Leboulanger.

\section{References}

Cardinale BJ (2011) Biodiversity improves water quality through niche partitioning. Nature 472:86-89

Caron DA (2000) Symbiosis and mixotrophy among pelagic microorganisms. In: Kirchman DL (ed) Microbial ecology of the oceans. Wiley, New York, pp 495-523

Chinnasamy S, Bhatnagar A, Claxton R, Das KC (2010) Biomass and bioenergy production potential of microalgae consortium in open and closed bioreactors using untreated carpet industry effluent as growth medium. Bioresour Technol 101:6751-6760

Costanza R, Kemp WM, Boynton WR (1993) Predictability, scale, and biodiversity in coastal and estuarine ecosystems: Implications for management. Ambio 22:88-96

Dismukes GC, Carrieri D, Bennette N, Ananyev GM, Posewitz MC (2008) Aquatic phototrophs: efficient alternatives to land-based crops for biofuels. Curr Opin Biotechnol 19: 235-240

Dubey SK, Dubey J, Mehra S, Tiwari P, Bishwas AJ (2011) Potential use of cyanobacterial species in bioremediation of industrial effluents. Afr J Biotechnol 10: $1125-1132$

Fouilland E, Mostajir B (2010) Revisited phytoplanktonic carbon dependency of heterotrophic bacteria in freshwaters, transitional, coastal and oceanic waters. FEMS Microbiol Ecol 73:419-429

Fouilland E, Mostajir B (2011) Complementary support for the new ecological concept of bacterial independence on contemporary phytoplankton production in oceanic waters. FEMS Microbiol Ecol 78:206-209

Fouilland E, Descolas-gros C, Courties C, Collos Y, Vaquer A, Gasc A (2004) Productivivty and growth of a natural population of the smallest free-living eukaryote under nitrogen deficiency and sufficiency. Microb Ecol 48:103-110

Granéli E, Carlsson P, Legrand C (1999) The role of C, N and P in dissolved and particulate organic matter as a nutrient source for phytoplankton growth, including toxic species. Aquat Ecol 33:17-27

Grover JP (2000) Resource competition and community structure in aquatic micro-organisms: experimental studies of algae and bacteria along a gradient of organic carbon to inorganic phosphorus supply. J Plankton Res 22:1591-1610

Jiang L, Luo S, Fan X, Yang Z, Guo R (2011) Biomass and lipid production of marine microalgae using municipal wastewater and high concentration of $\mathrm{CO}_{2}$. Appl Energy 88: 3336-3341

Li S-P, Li J-T, Kuang J-L, Duan H-N, Zeng Y, Shu W-S (2012) Effects of species richness on cadmium removal efficiencies of algal microcosms. J Appl Ecol 49:261-267

Logares R, Bråte J, Bertilsson S, Clasen JL, Shalchian-Tabrizi K, Rengefors K (2009) Infrequent marine-freshwater transitions in the microbial world. Trends Microbiol 17:414-422 
Muñoz R, Guieysse B (2006) Algal-bacterial processes for the treatment of hazardous contaminants: a review. Water Res 40:2799-2815

Ptacnik R, Solimini AG, Andersen T, Tamminen T, Brettum P, Lepistö L, Willén E, Rekolainen S (2008) Diversity predicts stability and resource use efficiency in natural phytoplankton communities. PNAS 105:5134-5138

Raven JA (1997) Phagotrophy in phototrophs. Limnol Oceanogr 42:198-205

Rawat I, Ranjith Kumar R, Mutanda T, Bux F (2011) Dual role of microalgae: phycoremediation of domestic wastewater and biomass production for sustainable biofuels production. Appl Energy 88:3411-3424

Rodolfi L, Chini Zitelli G, Bassi N, Padovani G, Biondi N, Bonini G, Tredici MR (2009) Microalgae for oil: strain selection, induction of lipid synthesis and outdoor mass cultivation in a low-cost photobioreactor. Biotechnol Bioeng 102:100-112

Simon N, Cras A-N, Foulon E, Lemée R (2009) Diversity and evolution of marine phytoplankton. Comptes Rendus Biologies 332:159-170

Stoecker DK (1999) Mixotrophy among dinoflagellates. J Eukaryot Microbiol 46:397-401

Subashchandrabose SR, Ramakrishnan B, Megharaj M, Venkateswarlu K, Naidu R (2011) Consortia of cyanobacteria/ microalgae and bacteria: Biotechnological potential. Biotechnol Adv 29:896-907

Tam NFY, Wong YS, Simpson CG (1997) Removal of copper by free and immobilized microalga, Chlorella vulgaris. In: Wong YS, Tam NFY (eds) Wastewater treatment with algae. Springer, Berlin, pp 17-36

Tang H, Abunasser N, Garcia MED, Chen M, Simon Ng KY, Salley SO (2011) Potential of microalgae oil from Dunaliella tertiolecta as feedstock for biodiesel. Appl Energy 88:3324-3330

Ventaka Mohan S, Prathima Devi S, Mohanakrishna M, Amarnath G, Lenin Babu N, Sarma M, P N (2011) Potential of mixed microalgae to harness biodiesel from ecological water-bodies with simultaneous treatment. Bioresour Technol 102:1109-1117

Wegmann K (1986) osmoregulation in eukaryotic algae. FEMS Microbiol Lett 39:37-43

Wide EW, Bennan JR (1993) Bioremoval of heavy metals by the use of microalgae. Biotechnol Adv 11:781-812

Wilkie AC, Edmundson SJ, Duncan JG (2011) Indigenous algae for local bioresource production: phycoprospecting. Energy Sustain Develop 15:365-371 